\title{
AISAS (Attention, Interest, Search, Action, Share) Model of Cosmetics Marketing Communication on Online Beauty Forum (Case-Study: Avoskin Marketing on Sociolla)
}

\author{
Nadia Humaira ${ }^{1}$ \\ ${ }^{1}$ Universitas Indonesia
}

\begin{abstract}
ABSTRAK
Di era digital, konsep AISAS (Attention, Interest, Search, Action, Share) relevan untuk menggambarkan perilaku audience dalam mengambil keputusan pembelian. AISAS menekankan pada dua perilaku konsumen yang unik, yaitu mengumpulkan dan berbagi informasi yang menjadi faktor penting dalam keputusan pembelian. Paradigma penelitian ini menggunakan paradigma postpositivis dengan pendekatan kualitatif, metode studi kasus dan jenis penelitian deskriptif menggunakan data yang ada atau tersedia berupa jejak digital yang diambil melalui waw ancara mendalam kepada informan yang berpengalaman berbelanja melalui Sociolla selain itu data diambil pada media online seperti situs resmi Sociolla (sociolla.com), forum online Soco by Sociolla (Soco.id), dan saluran media sosial Instagram Sociolla, khususnya konten pemasaran kosmetik Avoskin tahun 2020. Hasil penelitian ini menunjukkan bahwa pemasaran kosmetik (Avoskin) melalui forum online (Sociolla) memungkinkan khalayak dan konsumen untuk mengumpulkan dan berbagi informasi sebagai dirangkum dalam konsep AISAS. Fitur pendukung yang ada di Sociolla, seperti diskusi forum online, posting review, dan e-commerce, memasarkan kosmetik secara lebih informatif dan menggunakan pihak ketiga sebagai jembatan antara kosmetik dan audiens digital.
\end{abstract}

Kata Kunci: Komunikasi Pemasaran Kosmetik, Model Aisas, Forum Kecantikan Online

\section{ABSTRACT}

AISAS (Attention, Interest, Search, Action, Share) Model of Cosmetics Marketing Communication on Online Beauty Forum (Case-Study: Avoskin Marketing on Sociolla)

In the digital era, the concept of AISAS (Attention, Interest, Search, Action, Share) is relevant to describe audience behavior in making purchase decisions. AISAS emphasizes two unique consumer behaviors, namely collecting and sharing information that is an important factor in purchasing decisions. This research paradigm uses a postpositivist paradigm with a qualitative approach, case study methods, and descriptive research types using existing or available data in the form of digital traces taken through in-depth interviews with experienced informants through Sociolla besides data taken on online media such as the official Sociolla website ( sociolla.com), Soco by Sociolla (Soco.id) online forum, and Sociolla social media channels, especially Avoskin's 2020 cosmetic marketing content. The results of this study indicate that cosmetic marketing (Avoskin) through online forums (Sociolla) enables audiences and consumers to collect and share information as summarized in the AISAS concept. Supporting features in Sociolla, such as online discussion forums, posting reviews, and e-commerce, marketing cosmetics in a more informative way, and using a third party as a bridge between cosmetics and digital audiences.

Keywords: Cosmetics Marketing Communication, Aisas Models, Online Beauty Forum 
Korespondensi: Nadia Humaira. Universitas Indonesia. Alamat: Jl. Margonda Raya, Pondok Cina, Kecamatan Beji, Kota Depok, Jawa Barat 16424. No. WhatsApp: Email: nadiahumaira@gmail.com

\section{PENDAHULUAN}

Menghadapi revolusi industri 4.0 yang diperkenalkan pada tahun 2011, industri 4.0 dikenal sebagai trend di dunia industri, yang merupakan gabungan antara teknologi otomasi dan teknologi dunia maya dimana revolusi ini mengubah cara hidup, bekerja dan berkomunikasi. (Baenanda, 2019). Revolusi ini juga membentuk kembali berbagai sistem yang ada seperti pemerintahan, pendidikan, dan lainnya terutama perdagangan. Kementerian Perindustrian Indonesia menyampaikan bahwa pada industri 4.0, human and human efficiency mulai terkoneksi dengan lebih mudah melalui internet of things (IoT), cloud computing, dan kognitif computing (Rahayu, 2019; Debora, 2019).

Saat ini perkembangan internet di Indonesia terus meningkat. Data terbaru dari laporan We Are Social tahun 2020 menyebutkan terdapat 175,4 juta pengguna internet di Indonesia dan meningkat 17\% atau 25 juta pengguna internet dari tahun sebelumnya. Kemudian berdasarkan jumlah penduduk Indonesia sebesar 272,1 juta, artinya 64\% penduduk Indonesia telah mengalami akses dunia maya.

Di Indonesia, pemerintah telah membuat peta untuk menghadapi industri 4.0 yang mana sektor industri prioritas telah ditetapkan untuk memperjelas arah dan langkah strategis untuk menjadi negara yang lebih maju dan tangguh. Sektor industri yang menjadi prioritas adalah industri makanan dan minuman, tekstil dan pakaian, otomotif, elektronik dan kimia (Sindonews.com, 2019).

Pilihan kelima sektor ini karena sektor industri menyumbang 60\% dari pendapatan domestik bruto (PDB), menyumbang 65\% dari total ekspor selama ini, dan sekitar 60\% tenaga kerja industri berada di sektor industri prioritas ini. Fokus pembahasan dalam penelitian ini adalah strategi pemasaran digital yang dilakukan oleh local brand Avoskin dengan memanfaatkan forum online sebagai 'new media' untuk memasarkan produk kosmetik dan perawatan kulit. Kosmetik adalah salah satu cabang dari industri kimia yang sedang menjadi fokus pemerintah. Penting bagi industri ini untuk bisa memanfaatkan perubahan positif pada era industri 4.0. Strategi pemasaran digital dari brand Avoskin menarik untuk diteliti karena Avoskin merupakan salah satu produk skin care lokal terlaris di Indonesia (Tempo.co, 2020).

Salah satu platform digital yang digunakan Avoskin untuk memasarkan produknya di Indonesia adalah Sociolla. Sebagai sebuah forum yang mewadahi para wanita untuk berdiskusi secara online Sociolla telah menjadi virtual public sphere atau ruang publik baru di internet. Ruang publik ini memungkinkan terjalinnya pertukaran informasi secara simultan (interactivity) dan menjadi penghubung antara pemasar dengan konsumen (interconnectivity).

Fenomena ini menarik untuk diteliti karena kehadiran Sociolla sebagai sebuah media baru juga telah mengubah kebiasaan lama konsumen dan mempengaruhi cara mereka melakukan kegiatan sehari-hari hingga mempengaruhi konsumen dalam pengambilan keputusan (mediatisation). Selain itu, Sociolla memfasilitasi pengguna untuk menilai kualitas produk, baik dengan rating' (jumlah bintang) maupun dengan 'review' 
(ulasan pengalaman menggunakan produk) dalam bentuk post atau thread. Melalui fitur search (pencarian) dan share (pembagian) pengguna menjadi siklus yang saling berhubungan. Dengan melakukan pencarian, pengguna dapat mengurangi dan meminimalkan risiko sebelum membeli, juga pengguna dapat membandingkan informasi tentang suatu produk diperlukan sebelum membuat keputusan bertransaksi (Chuah, dkk, 2014).

Penelitian sebelumnya, pencarian informasi melalui Sociolla berdampak signifikan pada kepercayaan produk (Hidayanto, dkk, 2017). Selain itu, penelitian Wardani (2017) menyebutkan adanya pengaruh antara electronic word of mouth pada forum online Sociolla terhadap keputusan pembelian produk Purbasari di kalangan remaja wanita dan besarnya pengaruh dengan kategori kuat sebesar 64,3\%. Hasil tersebut sejalan dengan temuan Rahman \& Fuady (2018) dimana tingkat keeratan hubungan terhadap keputusan pembelian yang diulas dalam Sociolla sebesar 0,658. Penelitian ini ditujukan untuk memahami lebih dalam bagaimana konsep atau teori AISAS diterapkan dalam pemasaran produk Avoskin melalui platform digital Sociolla. Analisis penelitian ini berfokus pada penggunaan konsep atau teori AISAS oleh produk kosmetik Avoskin melalui platform digital yang dimiliki oleh Sociolla diantaranya website dan media sosial seperti Youtube dan Instagram

\section{METODE PENELITIAN}

Paradigma penelitian ini menggunakan paradigma post-positivisme. Paradigma ini dipilih karena paradigma post-positivisme mampu mengembangkan pernyataan yang relevan, menjelaskan situasi yang sebenarnya, dan mendeskripsikan relasi dari kausalitas suatu persoalan. Pada penelitian yang menggunakan paradigma post-positivisme ini, peneliti akan menekankankan penemuan dan pembuktian teori. Paradigma ini memiliki elemen kunci diantaranya: 1) determinasi; 2) reduksionisme; 3) observasi dan pengujian empiris; 4) verifikasi teori (Creswell, 2014). Filsafat post-positivistik cenderung reduksionistis karena orientasinya yaitu mereduksi gagasan-gagasan besar menjadi gagasan-gagasan terpisah yang lebih kecil untuk diuji lebih lanjut. Penelitian ini menggunakan pendekatan kualitatif deskriptif yang bertujuan menyajikan gambaran yang spesifik mengenai situasi, penataan sosial, atau hubungannya (Neuman, 2017). Penelitian kualitatif adalah aktivitas penelitian dengan menempatkan peneliti berada di dalam tempat dilakukannya penelitian tersebut (Denzin \& Lincoln, 2005). Penelitian kualitatif digunakan untuk mengungkap tren dalam pemikiran dan pendapat, dan menyelam lebih dalam ke masalah (DeFranzo, 2011).

Penelitian ini akan menggunakan metode studi kasus. Menurut Neuman (2013), strategi studi kasus adalah berupa penelitian yang menyelidiki secara mendalam dari berbagai informasi tentang beberapa kasus untuk satu periode atau antar beberapa periode majemuk. Lalu menurut Yin (1997), studi kasus adalah suatu inkuiri empiris yang menyelidiki fenomena di dalam konteks kehidupan nyata, bilamana batas antara fenomena dan konteks tak tampak dengan tegas dan di mana multi sumber bukti dimanfaatkan. Strategi studi kasus cocok diterapkan pada sebuah penelitian bilamana pokok pertanyaan penelitian berkenaan dengan how 
atau why, peneliti hanya memiliki sedikit peluang untuk mengontrol peristiwa-peristiwa yang akan diteliti, fokus penelitian terletak pada fenomena kontemporer atau masa kini dalam konteks kehidupan nyata (Yin, 1997).

Penelitian kualitatif melibatkan interpretasi dan pendekatan alami terhadap dunia yang sedang diamati. Hal ini berarti sebagai peneliti harus mengamati di dalam pengaturan alaminya, kemudian berusaha memahami, atau menafsirkan, fenomena dalam arti makna yang dibawa orang kepada mereka. Dalam penelitian digital, peneliti berhadapan dengan data raksasa (big data). Data tersebut berupa opini, sikap dan perilaku pengguna (mis. tercermin dalam posting di media sosial). Data tersebut membantu karena tersedia, always-on dan dalam jumlah sangat besar (Salganik, 2017). Penelitian ini menggunakan wawancara kepada 2 (dua) orang pengguna Sociolla.com untuk berbelanja produk Avoskin.

Selain itu penelitian in imenggunakan data yang sudah ada tercantum dalam media sosial Sociolla maupun aplikasi So.Co by Sociolla. Data tersebut telah ada sebelum kehadiran peneliti. Yang dibutuhkan adalah kemampuan dalam mengambil data / data retrieval (crawling atau mining data). Data tersebut kemudian disortir sesuai dengan kebutuhan (Queries) dan dianalisis.

Dalam penelitian ini, peneliti memperoleh data dengan menggunakan data yang sudah ada atau tersedia (Extant), jejak digital. Data tersebut telah ada sebelum peneliti melakukan penelitian, diantaranya dengan menggunakan studi dokumen dan arsip yang bersifat digital. Umumnya kebanyakan dokumen dan arsip yang dimaksud pada penelitian adalah bersifat fisik, namun dalam penelitian ini dokumen yang digunakan adalah semua jejak dokumen yang bersifat digital. Studi dokumen dipakai untuk menangani bahan-bahan dokumentasi. Bahan dokumentasi ini ada berbagai jenis, diantaranya: surat, memorandum, pengumuman resmi, agenda, laporan tertulis, dokumen-dokumen administratif, kliping dan artikel di media massa yang bersifat digital atau online, dan lain sebagainya. Dokumen-dokumen itu memang harus dimanfaatkan secara hati-hati, terutama sumber dari dokumen. Selain dokumen, teknik pengumpulan data juga dilakukan melalui rekaman arsip.

Rekaman arsip ada beberapa jenis, diantaranya: rekaman layanan, rekaman keorganisasian, daftar nama dan komoditi yang relevan, data survei, rekaman-rekaman publik atau jejak sosial media, dan lain sebagainya. Namun tidak seperti bukti dokumen, kegunaan rekaman arsip akan bervariasi pada satu studi kasus dan studi kasus lainnya. Pada beberapa penelitian, rekaman tersebut sangat penting sehingga bisa menjadi objek perolehan kembali dan analisis yang lebih luas. Dalam penelitian ini, analisis data dilakukan secara deskriptif kualitatif dan interpretatif. Dengan menyusun secara sistematis data yang diperoleh dari dokumen dan arsip yang sebelumnya sudah dilakukan pada teknik pengumpulan data. Menurut Miles dan Huberman dalam Ardianto (2016:223), ada tiga jenis kegiatan dalam analisis data: (1) Reduksi Data, adalah suatu bentuk analisis yang mempertajam, memilih, memfokuskan, membuang, menyusun data dalam suatu cara di mana kesimpulan akhir dapat digambarkan. Sehingga mempermudah peneliti untuk melakukan pengumpulan data selanjutnya dan mencarinya bila diperlukan; (2) Data Display, Setelah data direduksi maka langkah 
selanjutnya adalah mendisplay data. Dalam penelitian kualitatif, penyajian data bisa dilakukan dalam bentuk uraian singkat, bagan, hubungan antara kategori, dan lain-lain. Kemudian dilanjutkan dengan mendefinisikan uraian data sebagai suatu kumpulan informasi yang tersusun yang akan dilanjutkan kepada pendeskripsian kesimpulan dan pengambilan tindakan yang akan dilakukan selanjutnya. Bentuk yang paling sering dari model data kualitatif selama ini adalah teks naratif. (3) Penarikan/Verifikasi Kesimpulan. Dari permulaan pengumpulan data, peneliti kualitatif mulai memutuskan apakah makna sesuatu, mencatat keteraturan, polapola, penjelasan, konfigurasi yang mungkin, alur sebab-akibat, dan proposisi-proposisi. Temuan dapat berupa deskripsi atau gambaran suatu objek yang sebelumnya masih belum jelas sehingga setelah diteliti menjadi jelas.

\section{HASIL DAN PEMBAHASAN}

\section{Analisis Forum Online Sociolla pada Produk Avoskin}

Selain pemasaran konten dan media sosial, pemasaran video, e-mail, dan SEO yang telah dipaparkan sebelumnya, Avoskin juga memanfaatkan situs Sociolla yang merupakan sebuah virtual public sphere. Sociolla berawal dari online beauty blog online forum discussion, kemudian berubah menjadi User Generated Content (UGC) yang memungkinkan user untuk mem-posting review, baik dalam bentuk post atau thread.

Sociolla dimanfaatkan oleh para anggotanya (audiens) untuk mencari informasi mengenai produk kecantikan apa yang dirasa mampu untuk memenuhi kebutuhannya. Merujuk kepada penelitian yang dilakukan sebelumnya, ada beberapa hal yang mempengaruhi keputusan seseorang untuk menggunakan dan membeli sebuah produk, salah satunya adalah word of mouth. Word of mouth sendiri disini merupakan sebuah sebuah pertukaran informasi antara satu individu dan individu lainnya. Dimana individu yang telah memiliki informasi terhadap sebuah produk akan membagikan pengalaman dan pengetahuannya akan produk tersebut kepada individu lainnya yang belum mengetahui informasi tersebut. Informasi inilah yang dapat mengubah perilaku seseorang yang sebelumnya tidak ingin menggunakan atau belum pernah menggunakan produk tersebut menjadi ingin menggunakan produk tersebut (Kumadji \& Kusumawati, 2014).

Dalam era saat ini salah satu hal yang masih menjadi pokok pembahasan adalah konsep keaslian. Meningkatnya komersialisasi dan berbagai macam produk dengan fungsi yang kurang lebih hampir sama turut mengubah cara pandang konsumen dimana mereka saat ini memandang sesuatu yang asli adalah hal yang penting. Ketimbang mempercayai ulasan selebriti yang sudah dapat dipastikan bahwa hal tersebut palsu karena selebriti dibayar untuk mempromosikan suatu produk, konsumen lebih mempercayai para blogger atau saat ini sudah berkembang menjadi Video Blogger (Vlogger). Konsumen lebih mempercayai ulasan yang diberikan oleh para vlogger dan blogger tersebut dikarenakan, konten yang mereka berikan dapat dibilang 'asli'. Hal ini dipicu dari pandangan bahwa blogger dan vlogger biasanya hanya membuat, menulis dan mengunggah konten atau topik yang dianggap menarik oleh mereka sehingga mereka dianggap kredibel dan ahli. 


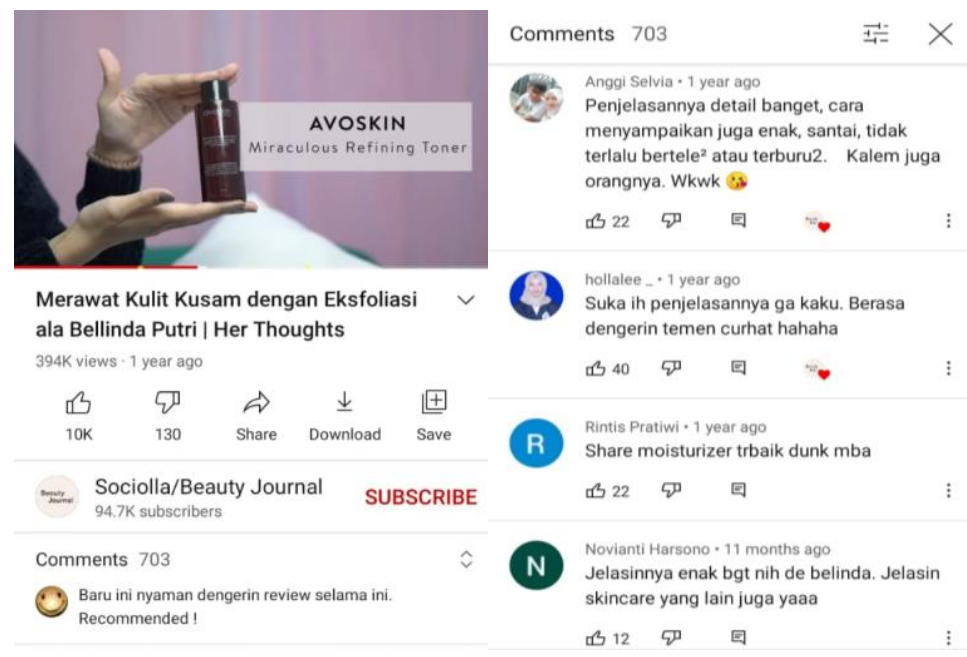

Gambar 4.1. Video Sociolla berisi ulasan produk Avoskin Sumber : Youtube Sociolla/Beauty Journal

Selain itu, kelebihan dari para blogger dan vlogger ini mereka dapat menawarkan pengalaman otentik kepada para konsumen (Forrest \& Cao, (2010); Willemsen, Neijens, Bronner \& Ridder, (2011); Lisichkova \& Othman, (2017)). Sociolla juga kerap mengadakan Beauty Awards sejak tahun 2018, dimana anggota dari Sociolla dapat memberikan vote kepada produk kecantikan yang dianggap bagus dan memiliki kualitas. Adapun beberapa kategori yang diberikan dalam Beauty Awards ini seperti Best Make-Up, Best Skin Care, Best Hair, Body \& Nails, Best Tools dan Best in Industry.

Produk dari Avoskin sendiri telah mendapatkan Beauty Awards dalam kategori Best Makeup dan Best Skin Care sejak tahun 2016, hingga kini di 2019 (Sociolla Awards, n.d.). Selain berdasarkan ulasan dari anggota dan juga Beauty Awards yang didapatkan oleh beberapa produk Avoskin tentunya selain meningkatkan paparan terhadap masyarakat terutama anggota dari Sociolla tentunya juga sebagai bentuk penilaian kualitas produk Avoskin. Kualitas produk sendiri merupakan kemampuan yang ada dalam suatu produk yang berguna untuk menjalankan fungsinya dimana hal ini mencakup keandalan, kemudahan, kemasan, daya tahan, fungsi dan lain sebagainya (Amstrong \& Kotler, 1997).

Dalam hal ini kualitas dari produk Avoskin ini sendiri, dipilih berdasarkan hasil vote user, yang telah pernah menggunakan produk Avoskin ini. Tidak hanya melalui aplikasi dan situs web, Sociolla juga menggunakan social media resmi, yakni melalui Instagramnya untuk mempromosikan produk Avoskin. Melalui instagramnya, Sociolla mengunggah foto produk beserta penjelasan mengenai kelebihan produk tersebut di keterangan gambar. Tidak hanya itu, Sociolla juga menandai akun instagram resmi @ Avoskinid dan menyertai tagar khusus brand Avoskin pada akhir keterangan.

Selain konten yang khusus membahas Avoskin, terdapat pula konten organik hasil ulasan redaksi Sociolla. Hal tersebut dapat terlihat dari produk Avoskin yang direkomendasikan Sociolla juga disejajarkan dengan produk-produk yang serupa milik kompetitor. Sebagai upaya untuk meningkatkan kesadaran terhadap merek, Sociolla juga menandai akun Instagram resmi Avoskin yaitu @ Avoskinbeauty. 

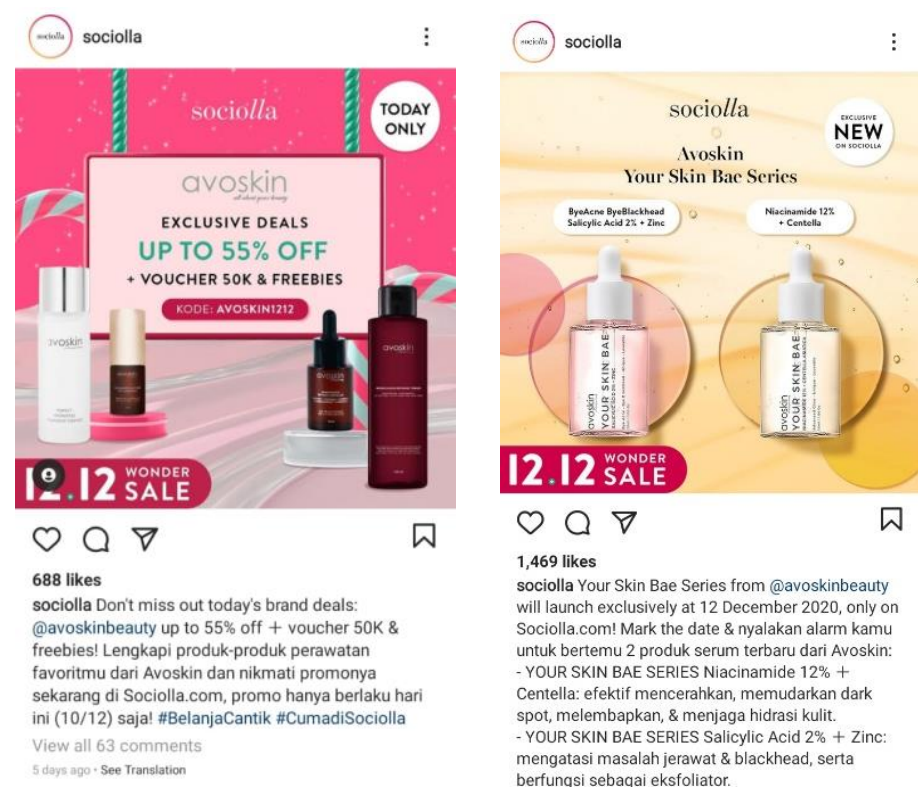

Gambar 4.2. Unggahan media sosial Instagram Sociolla berisi promosi produk Avoskin dimana tercantum foto barang dan tautan@avoskinbeauty

Sumber: Instagram Sociolla

Namun, tagar khusus terkait merek Avoskin tidak ditemukan di unggahan ini. Penggunaan media sosial lainnya, seperti Facebook dan Instagram tidak dioptimalkan oleh Femaledaily untuk mempromosikan produk Avoskin karena hanya digunakan untuk mempromosikan link artikelnya saja demi menaikkan traffic. Walaupun terkesan memiliki fungsi yang sama, pada hakikatnya, sebuah produk harus memiliki 'pembeda' yang dapat membedakannya dari kompetitornya (produk sejenis). Hal ini bisa dilihat dari pemberian nama, istilah, tanda, simbol, desain, harga, komposisi dan lain sebagainya. Hal ini menjadi penting supaya konsumen memahami dan juga memiliki awareness terhadap brand tertentu (Setyawan dan Adiwijaya, 2018). Sama halnya dengan Avoskin, yang mengusung komposisi Phyto Sugar Water yang berguna untuk melembabkan dan mencerahkan kulit. Sesuai dengan brand proposition yang selalu digunakan sebagai brand asal Korea Selatan. Hal ini juga semakin didukung dengan gambaran bahwa rata-rata kulit wajah perempuan Korea Selatan itu berkulit putih cerah dan dewy (Elia dan Sofyani, 2018). Konsep AISAS ini menggambarkan perilaku khalayak ketika akan membuat keputusan pembelian, yang mana sejalan dengan customer path 4.0 yang ketika membuat keputusan pembelian melalui tahapan aware - appeal - ask - act - advocate (Kurniawan, 2017). Tahapan ask atau search dalam AISAS menjadi salah satu ciri perilaku konsumen di era saat ini. Sebab pada dasarnya pencarian informasi punya dampak signifikan terhadap kepercayaan khalayak pada sebuah produk (Hidayanto, dkk, 2017). Oleh karena itu ketika khalayak sudah percaya pada produk maka makin memperbesar terjadinya pembelian produk.

Jika diurutkan konsep AISAS dari tahap awal attention sampai tahap akhir share pada produk Avoskin sebagai berikut:

a) Attention 
Attention merupakan tahap awal dimana khalayak terpapar dan memperhatikan stimulus berupa iklan baik dari media konvensional maupun digital. Misalnya pada produk Avoskin, iklan atau terpaan informasi berupa Youtube ads, artikel review produk pada Sociolla, maupun Instagram ads Avoskin. Informasi produk Avoskin yang didapatkan dari berbagai media tersebut, dapat menimbulkan kesadaran dari khalayak untuk memperhatikan produk Avoskin. Khalayak yang merupakan calon konsumen maupun konsumen akan terpapar informasi-informasi dari produk Avoskin. Khalayak akan memperhatikan stimulus berupa iklan yang

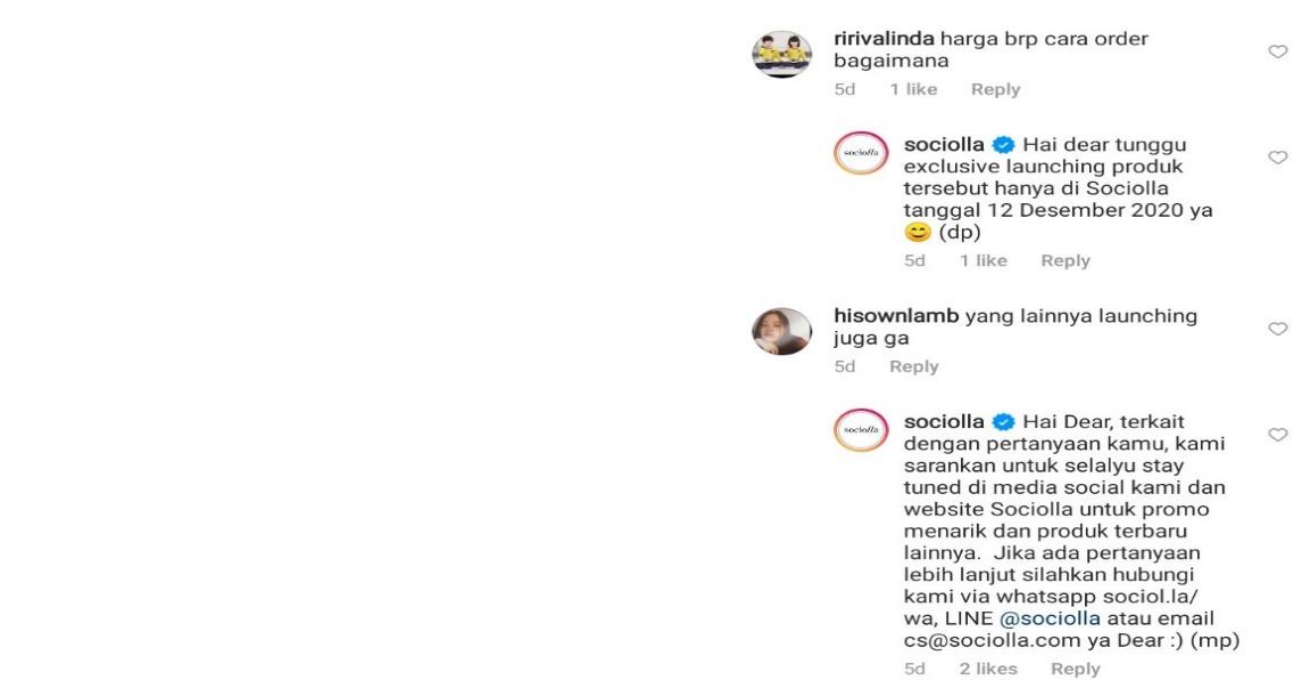

disiapkan oleh produk Avoskin dalam media-media yang sudah ditentukan.

\section{Gambar 4.3. Komentar warganet yang ditanggapi Sociolla} Sumber: Instagram Sociolla

Dalam Prasetyo dan Rachmawati (2016), mengukur attention dapat diketahui dengan seberapa banyak khalayak yang memperhatikan iklan online dan pesan pemasaran. Pada Sociolla, review produk yang diberikan akan menimbulkan kesadaran khalayak atas kelebihan dari produk Avoskin dibandingkan dengan produk-produk lainnya. Begitu pula dengan iklan yang muncul pada Youtube dan Instagram. Khalayak akan mendapatkan informasi terkait dengan kelebihan produk Avoskin dan efek yang akan didapatkan dari penggunaan produk Avoskin. Hal ini sesuai dengan tahap attention dalam AISAS, dimana kesadaran khalayak timbul untuk memperhatikan produk, layanan, dan iklan melalui sebuah media.

Informan 1:

"Pertama kali mengenal Sociolla pada akhir 2019 dari Instagram. Setelah itu dia mengetahui tentang Avoskin dari Youtube Vlogger Tasya farasya dan Suhay Salim. Saya telah membeli Avoskin PHTE dan toner penyulingan ajaib di Sociolla.com. Saya mengenal Avoskin karena ditampilkan di halaman utama Sociolla dengan diskon dan cashback. Avoskin juga menjadi pemenang best skincare 2019 yang merupakan best seller product dan sering kali sold out. Sociolla memiliki tampilan dan eye cacthing yang menarik. Saya tertarik membeli Avoskin di Sociolla karena di sana banyak promo seperti diskon dan cashback."

Informan 2:

"Pertama kali mengetahui adalah Sociolla, tapi saya belum pernah membuka halaman Sociolla. Saya menemukan Avoskin di Instagram, kemudian saya tahu penempatan Avoskin itu mudah untuk dibeli di Sociolla. Saya membeli seri dan ampul 'your skin bae'. Saya tertarik membeli Avoskin di Sociolla karena di Sociolla banyak memberikan diskon dan promosi.”

Hal ini menunjukkan bahwa semakin tinggi tingkat perhatian calon konsumen terhadap suatu produk baru, maka semakin tinggi pula niat calon konsumen untuk mengambil keputusan pembelian (Birkner, 2011). Semakin tinggi minat calon konsumen terhadap suatu produk, maka semakin tinggi pula aktivitas konsumen dalam mencari informasi (Lagrose, 2005). Pengenalan produk secara umum juga bertujuan untuk mendapatkan perhatian konsumen agar konsumen dapat mengambil keputusan pembelian. Semakin tinggi perhatian konsumen maka semakin tinggi pula keputusan pembelian yang mungkin dilakukan oleh konsumen (Shepher et al., 2016)

a)Interest

Berkaitan dengan tahap attention sebelumnya, setelah khalayak terpapar dengan berbagai jenis iklan dari produk Avoskin, kemudian pada tahap interest, muncul ketertarikan pada produk Avoskin. Sebagai bentuk respon atas pesan yang diterima, khalayak menjadi memiliki rasa 
ketertarikan untuk mencoba menelusuri lebih lanjut tentang produk Avoskin melalui berbagai channel atau saluran sehingga dapat mendalami informasi tentang produk Avoskin. Selain itu berbagai review yang menceritakan pengalaman orang lain yang telah menggunakan produk Avoskin juga dimanfaatkan sebagai pengetahuan akan produk tersebut. Hal yang dilakukan oleh khalayak ini sesuai dengan tahap interest dalam AISAS, dimana khalayak yang terpapar atas pesan produk maupun layanan, khalayak mulai tertarik terhadap produk atau layanan tersebut dan mulai merespon pesan yang diterimanya dan timbul rasa ingin mendalami informasi.

Hal ini juga relevan dengan sebuah penelitian serupa yang dibuat oleh Fidyah (2017), ia menyimpulkan bahwa pada tahap interest, iklan produk kecantikan Wardah melalui media sosial Instagram, efektif membuat konsumen berminat pada produk yang diiklankan. Ketertarikan muncul karena visualisasi iklan yang menarik dan juga persepsi baik dari konsumen terhadap produk yang diiklankan, sehingga konsumen berminat terhadap produk Wardah tersebut.

\section{b)Search}

Search merupakan tahap dimana khalayak aktif mencari segala informasi terkait, yang biasanya dilakukan melalui media sosial Avoskin salah satunya Instagram, website, atau forum online Sociolla. Namun tidak hanya berhenti di review produk termasuk bagaimana cara penggunaannya, kapan, dan efeknya pada jenis kulit yang berbeda namun juga tempat membelinya. Mereka tidak jarang bertanya dan berbagai akun online shop yang ada di e-commerce ataupun Instagram yang menurut mereka menawarkan harga yang murah. Pada tahap ini, review dari orang lain yang berpengalaman terkait produk Avoskin juga dapat mempengaruhi dan menjadi referensi khalayak dalam membuat keputusan. Khalayak mencoba menelusuri lebih lanjut tentang produk Avoskin melalui berbagai channel atau saluran sehingga khalayak dapat benar-benar mengerti terkait berbagai informasi atas produk Avoskin.

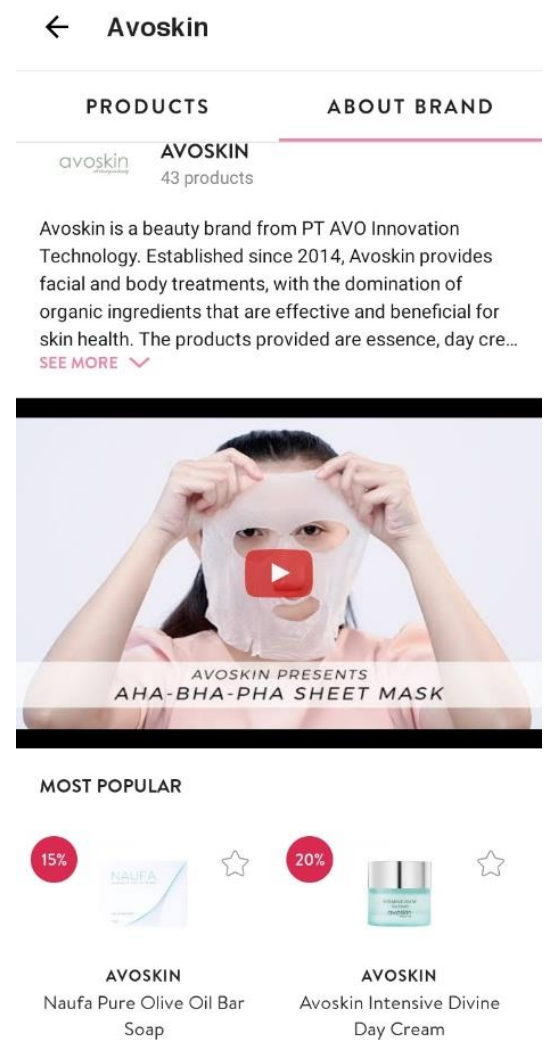

Gambar 4.4. Kolom 'About Brand' atau penjelasan melalui teks, video, dan display produk Avoksin yang tercantum pada Aplikasi So.Co by Sociolla

Hal tersebut merupakan bentuk rasa ketertarikan yang semakin mendalam terhadap produk Avoskin. Hal yang dilakukan oleh khalayak ini sesuai dengan tahap search pada tahap AISAS dimana pada tahap search ini, saat khalayak memiliki rasa ketertarikan yang semakin mendalam, khalayak akan secara aktif melakukan pencarian informasi terhadap produk atau layanan yang dilihat. Bentuk pencarian dan pengumpulan informasi dapat berupa mendatangi toko fisik, melakukan pencarian melalui search engine optimization, maupun 
melihat review mengenai produk maupun layanan yang diminati

\section{a) Action}

Tahapan dimana setelah mendapatkan banyak informasi terkait produk dan konsumen merasa kebutuhan akan informasi produk Avoskin terpenuhi serta informasi tentang produk positif, maka konsumen akan memutuskan membeli dan menggunakan produk Avoskin. Avoskin menerapkan AISAS yang diawali dengan 360 derajat marketing di mana untuk mendapatkan attention atau perhatian dari konsumen kini tidak hanya melalui iklan konvensional akan terapi iklan digital. Hal tersebut dapat terlihat pada halaman forum diskusi online Sociolla dimana audiens dapat berinteraksi dengan sesamanya untuk saling bertukar pendapat baik saat sesudah melakukan action ataupun pada saat mempertimbangkan sebelum membelinya. Tidak hanya melalui halaman forum diskusi online, audiens juga dapat memberikan ulasan produk secara khusus di halaman masing-masing produk Avoskin pada aplikasi Sociolla dan memberikan rating berupa bintang atas produk tersebut. Di halaman Sociolla terdapat pilihan "add to bag" atau "beli sekarang" di Sociolla. Audiens dapat memilih "beli sekarang" di halaman yang sama tanpa menutup halaman review. Sociolla memberikan voucher dan poin. Pilihan pembayaran tersedia untuk menggunakan e-wallet atau transfer bank. Hal ini pun diakui informan memudahkan transaksi pembelian produk.

Informan 1:

"Sociolla banyak memberikan diskon dan cashback. Saya membayar menggunakan Gopay atau transfer bank."

Informan 2:

"Saya kira kalau mau mencoba produk Avoskin tertentu harus beli di Sociolla. Saya memilih Sociolla karena ketersediaan produk dan diskonnya, itu karena diskonnya besar. Avoskin banyak memberikan promo di Sociolla dan Sociolla memberikan gratis ongkos kirim. Bayarannya juga gampang, bisa pakai GoPay."

Berbagai action yang dilakukan oleh khalayak atau konsumen merupakan bentuk-bentuk tindakan atas berbagai informasi yang didapatkan oleh khalayak atau konsumen itu sendiri. Khalayak atau konsumen yang memutuskan untuk membeli produk Avoskin telah merasa dan mengetahui bahwa produk Avoskin tersebut bagus dan memiliki efek baik serta cocok terhadap dirinya sehingga ia memutuskan untuk membeli produkproduk Avoskin tersebut. Tindakan publik pada tahap ini terkait dengan pengambilan keputusan tentang pembelian, adopsi, atau pembatalan keputusan tentang pembelian produk atau jasa (Sugiyama, 2011). Semakin tinggi perhatian konsumen maka semakin tinggi pula keputusan pembelian yang mungkin dilakukan oleh konsumen (Yu et al., 2018)

Semakin tinggi tingkat minat konsumen terhadap suatu produk maka semakin tinggi pula niat keputusan pembelian yang akan dibuat oleh konsumen dalam proses pembelian (Pan et al., 2018)Hal yang dilakukan oleh khalayak atau konsumen ini sesuai dengan tahapan action dalam AISAS, dimana action merupakan tindakan khalayak yang dapat berupa membuat keputusan akan membeli, mengadopsi, maupun membatalkan keputusan akan pembelian produk atau layanan. Hasil studi Hidayanto, dkk (2017) mengenai Sociolla 
menyebutkan bahwa kepercayaan terhadap produk dipengaruhi secara signifikan oleh electronic word of mouth.

\section{b) Share}

Tahapan akhir dimana setelah mendapatkan produk dari Avoskin, maka khalayak akan berbagi pengalamannya melalui media sosial, atau menulis review tentang produk Avoskin di Sociolla. Tahapan ini juga menjadi ciri khas terkait perilaku konsumen di era digital dimana pada akhirnya cerita yang dibagi ini akan kembali menjadi informasi pada tahapan 'search' bagi orang lain ketika mencari informasi terkait produk Avoskin selanjutnya. Behaviour para pembeli produk tidak hanya berhenti saat membeli produknya saja.

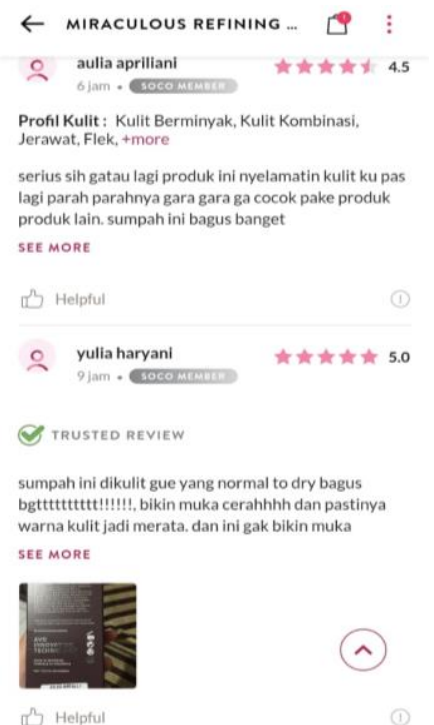

Gambar 4.17 - Ulasan salah satu pengguna setelah menggunakan produk Avoskin Miraculos Refining Toner di halaman Sociolla.com Sumber: Sociolla.com

Jika konsumen mengalami kepuasan maka hal tersebut akan mereka salurkan pada media sosialnya. Begitu pula jika konsumen mengalami kekecewaan terhadap suatu produk, maka akan menghasilkan review yang buruk pula. Jejak-jejak review dari produk inilah yang akan berputar kembali menjadi marketing funnel yang baru untuk orang lain. Pada tahap share ini, akan memperlihatkan bagaimana kualitas produk yang kita jual. Data scientist sangat dibutuhkan pada tahap ini. Seorang data scientist akan mengambil sentiment dari berbagai macam percakapan yang ada di media sosial dan mengambil kesimpulan tentang apakah produk tersebut memuaskan konsumen atau tidak. Jika ternyata tidak memuaskan, maka produk tersebut harus diperbaiki dan marketer harus berusaha untuk membenahi citra produknya kembali. Di halaman Sociolla Audiens bisa memberikan review tentang Sociolla, apalagi ada "Trusted Reviewer" untuk "jaminan" review produknya. So.Co by Sociolla memiliki beberapa fitur seperti Trending Photos, Trending Collection, Trending Articles, Trending Videos, Most Review Products, New Reviews, Top Reviewers.

\section{Informan 1}

"Saya memberi review di So.Co untuk 'Cosrx' bukan Avoskin. Saya juga memberikan review dan rekomendasi saya untuk membeli Avoskin di Sociolla, yang saya tahu dia membeli Avoskin Miraculous Toner."

Informan 2 
"Sayangnya saya belum pernah memberikan review tentang Avoskin di Sociolla. Tapi saya sering memberitahu teman-teman lain bahwa produk Avoskin di Sociolla sudah lengkap. Setelah saya review dan rekomendasi, beberapa teman saya membeli Avoskin di Sociolla."

Acara sosial untuk berbagi informasi dan pengalaman dapat membentuk kesan pembeli terhadap barang atau organisasi yang ditawarkan oleh afiliasi bisnis. Informasi dapat diteruskan dengan cepat dan mengikuti pengaruh garis ini (Woodcock et al., 2011). Perhatian konsumen terhadap suatu produk menimbulkan berbagai tanggapan, salah satunya adalah dengan membagikan informasi yang mereka dapatkan kepada orang lain secara online. Semakin tinggi perhatian konsumen terhadap produk maka semakin tinggi pula niat untuk berbagi informasi yang mereka dapatkan (Hendriyani et al., 2013). Tindakan konsumen berupa berbagi informasi dan pengalaman tentang suatu produk atau jasa. Bentuk sharimodel ini bisa dalam bentuk word of mouth atau e-WoM, melakukan review di halaman e-Commerce, atau membuat postingan di akun media sosial. Jika audiens memberikan cerita yang positif, maka secara tidak langsung audiens tersebut telah menjadi penginjil untuk produk atau merek yang ia bagikan. (Sugiyama dan Andree, 2011). Semakin tinggi niat untuk mencari informasi oleh konsumen maka semakin tinggi pula niat konsumen untuk berbagi informasi yang mereka dapatkan (Morris et al., 2012). Dalam strategi pemasaran yang dilakukan oleh produk Avoskin, dengan memanfaatkan situs Sociolla sebagai jembatan interaksi antara produsen dan konsumen dirasa cukup ampuh. Karena terbukti apabila konsumen telah memberikan ulasan mereka, terlebih apabila ulasannya kebanyakan ulasan positif, dan calon konsumen akan membacanya. Maka secara tidak langsung hal tersebut sudah menarik perhatian calon konsumen untuk membeli produk AvoskinKhalayak atau konsumen saat ini tidak hanya menikmati produk Avoskin sendiri tetapi juga berbagi pengalamannya atas pemakaian produk Avoskin. Kegiatan seperti memberikan ulasan pada halaman e-commerce maupun memberikan ulasan pada social media pribadi juga pada forum Sociolla telah menunjukkan perilaku konsumen untuk dapat berbagi pandangan dan pengalaman atas produk Avoskin. Hal yang dilakukan oleh khalayak atau konsumen ini sesuai dengan tahap share pada AISAS, dimana share merupakan tindakan konsumen berupa membagi informasi dan pengalamannya tentang produk atau layanan. Bentuk sharing dari model ini dapat berupa word of mouth atau $e$-WoM, melakukan ulasan pada halaman e-Commerce, atau membuat posting di akun media sosial. Apabila khalayak memberikan cerita positif, maka secara tidak langsung khalayak tersebut telah menjadi evangelist bagi produk atau brand yang ia bagikan.

Sesuai dengan penelitian yang dilakukan oleh Laksananto dan Mawardi (2017) tentang strategi pemasaran produk kosmetik dalam negeri dengan merek Emina. Dalam penelitiannya dengan berdasarkan hasil pengamatan penulis dan didasari oleh wawancara, penerapan strategi pemasaran Emina dengan memanfaatkan e-commerce memberikan pengaruh yang signifikan. 


\section{SIMPULAN}

Produk kecantikan Avoskin telah menerapkan pemasaran digital melalui konsep AISAS. Pengaplikasian pemasaran digital yang diterapkan oleh Avoskin yaitu pada pemasaran konten, pemasaran video, pemasaran email, dan pemasaran melalui media sosial. Avoskin menerapkan AISAS yang diawali dengan 360 derajat marketing di mana untuk mendapatkan attention atau perhatian dari konsumen kini tidak hanya melalui iklan konvensional akan terapi iklan digital juga memiliki peranannya. Pergeseran konsumsi publik dalam mengakses informasi terutama produk, membuat Avoskin mempromosikan tidak hanya pada akun sosial media Avoskin saja akan tetapi hampir di semua platform digital, termasuk di Sociolla. Tahapan selanjutnya yaitu interest di mana konsumen merasa tertarik dengan produk dan ada rasa ingin untuk membeli dan mencoba produk tersebut. Tahapan berikutnya konsumen akan mencari tahu tentang produk, pada tahap ini semua iklan di media digital memiliki peranan. Konsumen lebih cenderung mencari informasi produk dengan browsing di internet. Konsumen juga memiliki kecenderungan untuk lebih percaya pada informasi yang diberikan oleh pengguna produk atau hasil review produk dibandingkan dengan iklan official dari Avoskin. Pada tahapan ini Sociolla sebagai platform produk kecantikan wanita memiliki peranan sebagai tempat informasi dan review pengguna atas produk-produk kecantikan. Di samping itu Sociolla juga memberikan wadah untuk berdiskusi produk kecantikan sehingga pengguna dapat menulis review produk secara terbuka dan menjadi sumber terpercaya. Tahapan selanjutnya adalah action, tahap di mana konsumen merasa informasi tentang produk yang diinginkan sudah cukup dan jelas untuk konsumen membuat keputusan akan membeli produk atau tidak. Pada tahapan ini baik atau buruknya review sebuah produk sangat mempengaruhi keputusan membeli. Pada tahapan akhir yaitu share, pengalaman konsumen atas produk yang digunakan sangat penting dan berpengaruh atas review yang akan ditulis. Konsumen yang puas akan pengalamannya menggunakan produk memiliki kesempatan lebih besar untuk menuangkan reviewnya dengan ulasan yang positif. Demikian juga dengan konsumen yang memiliki pengalaman tidak memuaskan atas produk yang digunakan. Pada akhirnya, tulisan pengalaman dari pengguna atau review tersebut akan menjadi informasi bagi konsumen lain yang ingin mencari tahu tentang produk terkait. Sehingga AISAS dapat disimpulkan sebagai rantai komunikasi pemasaran yang saling berkesinambungan antara tahapan satu dan lainnya.

\section{DAFTAR PUSTAKA}

\section{Buku dan Journal}

Ardianto, Elvinaro. (2016). Metodologi Penelitian Untuk Public Relations. Bandung: Simbiosa.

Başyazıcıoğlu, Hayriye \& Karamustafa, Kurtulus. (2019). Marketing 4.0: Impacts Of Technological Developments On Marketing Activities

Chaffey, D., \& Ellis-Chadwick, F. (2019). Digital Marketing: Strategy, Implementation, and Practice. (7th Edition, Ed.). New York: Pearson.

Chua, W. F. (1986). Radical Developments in Accounting Thought. The Accounting Review, 61(4), 601-632. Retrieved from https://edisciplinas.usp.br/pluginfile.php/1495098/mod_resource/content/0/Chua_1986-Radical Developments in Accounting Thought.pdf

Das, Abhishek. (2018). Applications of Digital Marketing for Success in Business. BPB Publications.

Denzin, N. K., \& Lincoln, Y. A. (2005). The Sage Handbook of Qualitative Research (Third Edit). London: Sage Publications. 
https://books.google.co.id/books?id=X85J8ipMpZEC\&pg=PR5\&hl=id\&source=gbs_selected_pages\&cad=3 $\# \mathrm{v}=$ onepage \&q\&f=false

Fidyah, N. (2017). Efektivitas Iklan Produk Kosmetik Wardah Melalui Media Sosial Instagram. Skripsi.

Fourie, Pieter J. (2017) Normative media theory in the digital media landscape: from media ethics to ethical communication, Communicatio, 43:2, 109-127, DOI:10.1080/02500167.2017.1331927Forrest, E. \& Cao, Y. (2010). Social Media: Opinions, Recommendations and Endorsements: The New Regulatory Framework. Journal of Economic and Public Policy,5(2), 92-103.

Guba, E. G., \& Lincoln, Y. S. (1994). Competing Paradigms in Qualitative Research. In Handbook of Qualitative Research (3rd Ed, pp. 105-117). London: Sage Publications. Retrieved from https://eclass.uoa.gr/modules/document/file.php/PPP356/Guba \%26 Lincoln 1994.pdf

Hardt, M., and A. Negri. (2012). Declaration. New York: Argo-Navis.

Hendriyani, Jessica Jane, Lenny Ceng, Nabilah Utami, Reinata Priskila, Stefania Anggita. (2013). Online Consumer Behavior: Confirming the AISAS Model on Twitter Users. International Conference on Social and Political Sciences (ICSPS).

Hidayanto, Achmad Nizar, dkk (2017). The Roles of Electronic Word of Mouth and Information Searching in the Promotion of a New E-Commerce Strategy: A Case of Online Group Buying in Indonesia. Journal of Theoretical and Applied Electronic Commerce Research. Vol. 12 Issue 3 p. 69-85. DOI: 10.4067/S071818762017000300006

Intven, H. (2000). Telecommunications Regulation Handbook 3: Interconnection. Washington DC: McCarthy Tétrault. Jäckel, Michael, (1995) "Interaktion. Soziologische Anmerkungen zu einem Begriff”, Rundfunk und Fernsehen, no. 4. Jimenez-Zarco, Ana \& Rospigliosi, Asher \& Martinez-Ruiz, María Pilar \& Yusta, Alicia. (2017). Marketing 4.0: 10.4018/978-1-5225-2139-6.ch005.

Kirk, C., Chiagouris, L., \& Gopalakrishna, P. (2012). Some people just want to read: The roles of age, interactivity, and perceived usefulness of print in the consumption of digital information products. Journal Of Retailing And Consumer Services, 19(1), 168-178. doi: 10.1016/j.jretconser.2011.11.006

Kopetz, H. (2011). Internet of things. In Real-time systems (pp. 307-323). Springer, Boston, MA.

Kotler, P., Kartajaya, H., \& Setiawan, I. (2017). Marketing 4.0: Moving from traditional to digital.

Laksananto, Z. I., \& Mawardi, M. K. (2017). Analisis Strategi Pemasaran E-Commerce Pada Produk Kosmetik Buatan Dalam Negeri Di Kota Malang (Studi pada PT. Emina pada tahun 2017), 64(2), 11-18.

Lilleker, D. G. (1997). Key Concepts in Political Communication. SAGE Key Concept (Vol. 35). https://doi.org/10.5860/choice.35-2372

Lisichkova, N., \& Othman, Z. (2017). The Impact of Influencers on Online Purchase Intent (Master's thesis, Mälardalen University, Sweden).

Liu, Y., Shrum, L.J., 2009. A dual-process model of interactivity effects. Journal of Advertising 38 (2), 53-68.

Meilyana, Elizabeth. 2018. AISAS MODEL. http://bbs.binus.ac.id/international-marketing/2018/08/aisas-model/

Neuman, W. L. (2017). Metodologi Penelitian Sosial: Pendekatan Kualitatif dan Kuantitatif (Edisi 7). Indeks.

Papacharissi, Z. (2002). The virtual sphere. New Media \& Society, 4(1), 9-27. https://doi.org/10.1177/14614440222226244

Papacharissi, Z. (2009a). Handbook of Internet Politics. Handbook of Internet Politics, 1-35. https://doi.org/10.1111/1478-9302.12016_66

Papacharissi, Z. (2009b). The Virtual Sphere 2.0: The Internet, the Public Sphere and beyond. Handbook of Internet Politics, (1985), 1-35. https://doi.org/10.1111/1478-9302.12016_66

Permadi, P. C., Kumadji, S., \& Kusumawati, A. (2014). Pengaruh Citra Merek Terhadap Word fo Mouth dan Keputusan Pembelian (Survei pada Konsumen Dapoer Mie Galau Jalan Selorejo 83 Malang). Jurnal Administrasi Bisnis, Vol. 10, No. 1.

Prasetyo, Herdi \& Rachmawati Indira. (2016). Analisis Aisas (Attention, Interest, Search, Action, Share) Pada Pengguna Asus Zenfone di Indonesia. e-Proceeding of Management: Vol.3, No.3 December 2016.

Rafaeli, Sheizaf, (1988) "Interactivity. From New Media to Communication", in Robert P. Hawkins, John M. Wiemann \& Suzanne Pingree (eds.): Advancing Communication Science: Merging Mass and Interpersonal Processes, Newbury Park.

Rafaeli, Sheizaf, (1997) Networked Interactivity. Journal of Computer-Mediated Communication, Volume 2, Issue 4, 1 March 1997, JCMC243, https://doi.org/10.1111/j.1083-6101.1997.tb00201.x

Rahman, Fauzia Naufar \& Fuady, M.E. Hubungan antara Electronic Word of Mouth pada Website Femaledaily.com dengan Citra Merek Produk Kosmetik Wardah di Kalangan Mahasiswi. Unisba Volume 4, No. 2, Tahun 2018 Prosiding Hubungan Masyarakat ISSN: 2460-6510.

Redmond, W. H. (2004). Interconnectivity in diffusion of innovations and market competition. Journal of Business Research, 57(11), 1295-1302. doi: 10.1016/s0148-2963(02)00453-8 
Sathya, P. (2017). A Study on Digital Marketing and its Impact, 6(2), 2015-2017. Retrieved fromhttps://lp2m.asia.ac.id/wp-content/uploads/2018/04/7.-JURNAL-THERESIA-JIBEKA-VOL-11-NO-2FEB-2017.pdf

Setyawan, J. L., \& Adiwijaya, M. (2018). Pengaruh Brand Awareness, Brand Experience, dan Word of Mouth terhadap Purchase Decision pada Konsumen Baskhara Futsal Arena Surabaya. AGORA, 6(1).

Strömbäck, Jesper. (2008). Four Phases of Mediatization: An Analysis of the Mediatization of Politics. International Journal of Press-politics - INT J PRESS-POLIT. 13. 228-246. 10.1177/1940161208319097.

$\mathrm{Su}, \mathrm{W}$. (2016). A virtual public sphere and its limitations - microblog, online civic engagement in China and its interplay with the state. Journal of International Communication, 22(1), 1-21. https://doi.org/10.1080/13216597.2015.1076734

Sugiyama, Kotaro. Et al. (2011). The Dentsu Way. New York: McGraw Hill

Suet Nie, Kho \& Peng Kee, Chang \& Ahmad, Abdul. (2014). Mediatization: A Grand Concept or Contemporary Approach?. Procedia - Social and Behavioral Sciences. 155. 10.1016/j.sbspro.2014.10.306.

Todor, R. D. (2016). Blending traditional and digital marketing, 9(1). The University of Brasov

Wardani, Annisa Kesuma (2017) Pengaruh Electronic Word Of Mouth Pada Forum Online Sociolla Terhadap Minat Beli Produk Purbasari di Kalangan Remaja Wanita. JOM FISIP Vol. 4 No. 2 Oktober - 2017. https://media.neliti.com/media/publications/131635-ID-pengaruh-electronic-word-of-mouth-pada-f.pdf

Willemsen, L., Neijens, P.C., Bronner, P. \& Ridder, J.A. (2011). Highly recommended! The content characteristics and perceived usefulness of online consumer reviews. Journal of Computer-Mediated Communication, 17(1), 1938

Wsi, 2013. Digital Minds: 12 Things Every Business Needs to Know about Digital Marketing. Victoria: Friesen Press, p. 7.

Y. N. Pelawi, Irwansyah and M. P. Aprilia (2019), "Implementation of Marketing Communication Strategy in Attention, Interest, Search, Action, and Share (AISAS) Model through Vlog," 2019 IEEE 4th International Conference on Computer and Communication Systems (ICCCS), Singapore.

\section{Sumber Internet:}

American Marketing Association. (2019, February 22). What is Marketing? ? The Definition of Marketing ? AMA. Retrieved from https://www.ama.org/the-definition-of-marketing-what-is-marketing/

Amore Pacific. (n.d) About Brand Avoskin. Retrieved December 17, 2019, from https://www.apgroup.com/int/en/brands/Avoskin.html

Barone, A. (2019). Digital Marketing. Retrieved from https://www.investopedia.com/terms/d/digital-marketing.asp https://us.Avoskin.com/regimen/

Definition of Digital Marketing. Retrieved December 20, 2019, from http://markets.ft.com/research/Lexicon/Term?term=digital-marketing

Elia, S., \& Sofyani, F. (2018, August 11). Ada 3 Tren Skincare di Korea Selatan, Mana yang Anda Ketahui? Retrieved from https://kumparan.com/kumparanstyle/ada-3-tren-skincare-di-korea-selatan-mana-yang-anda-ketahui1533814983435185592

Sociolla. (n.d.). ABOUT BEST OF BEAUTY AWARDS. Retrieved December 15, 2019, from http://awards.femaledaily.com

Koran Sindo. (2019). Revolusi Industri 4.0, Ancaman dan Peluang. Retrieved December 15, 2019, from https://nasional.sindonews.com/read/1439542/16/revolusi-industri-40-ancaman-dan-peluang- 1568407320

Kurniawan, S. (2017, February 20). Memahami Marketing 4.0 dalam Konteks Ekonomi Digital. Retrieved from http://marketeers.com/mengenal-marketing-4-0-dalam-konteks-ekonomi-digital/

Ponnappa, S. (2019, August 23). What is a 'Super App?? Retrieved from https://blog.gojekengineering.com/what-is-asuper-app-4f2d889451e6.

Pratiwi, Hesti. (2014). Retrieved December, 18, 2019 from https://dailysocial.id/post/hanifa-ambadar-ceo-female-dailynetwork-bicara-tentang-membangun-komunitas

Ramaswamy, S. (2015). How Micro-Moments Are Changing the Rules. Retrieved May 19, 2019, from https://www.thinkwithgoogle.com/marketing-resources/micro-moments/how-micromoments-are-changingrules/ 